\title{
Winter crops affecting seed germination and early plant growth of corn and soybean
}

\author{
Culturas de inverno afetam germinação de sementes e crescimento inicial de plantas de milho e \\ soja
}

Mirian Fracasso Fabiani ${ }^{1}$, Leonardo Bianco Carvalho $0^{1,2^{*}}$, Wilson Roberto Cerveira Júnior ${ }^{2}$, Arthur
Arrobas Martins Barroso ${ }^{3}$ and Ricardo Alcántara de la Cruz $^{4}$

${ }^{1}$ Universidade do Estado de Santa Catarina, Lages, SC, Brasil.

2Universidade Estadual Paulista, Jaboticabal, SP, Brasil. *Autor para correspondência: leonardo.carvalho@unesp.br.

3Universidade Federal do Paraná, Curitiba, PR, Brasil.

${ }^{3}$ Universidade Federal de São Carlos, São Carlos, SP, Brasil.

Submission: 16/08/2017 / Acceptance: 01/03/2019

\begin{abstract}
The seed germination and the early plant growth of corn (Zea mays) and soybean (Glycine max) sowed after cropping and under straw residues (simulating crop rotations) of oat (Avena sativa), ryegrass (Lolium multiflorum) and wheat (Triticum aestivum) were investigated in pot experiments carried out under controlled conditions. The germination rates ranged from 78 to $95 \%$ (corn) and from 68 to $97 \%$ (soybean), while the speed emergence index ranged from 0.9 to 1.3 (corn) and from 0.7 to 0.12 (soybean). The lowest germination rates and speed emergence indexes occurred in crop rotation for wheat (corn) and ryegrass (soybean). In addition, the highest seedling emergence average time occurred in the crop rotation for wheat (corn) and ryegrass (soybean). On the other hand, the crop rotation for oat affected neither the speed emergence index nor the seedling emergence average time, despite causing a slight reduction of the seed germination (corn and soybean) and the shoot length (corn). Except for the crop rotation for ryegrass (soybean), the total dry mass of corn and soybean reduced when winter crops were previously cultivated. These results suggest that a delay and a reduction of seed germination and seedling emergence can occur in subsequent summer crops, depending on the winter species previously cropped, impacting on the early growth of summer crops.
\end{abstract}

KEYWORDS: allelopathy, cover crops, Glycine max, Zea mays.

\section{RESUMO}

A germinação de sementes e o crescimento inicial de plantas de milho (Zea mays) e soja (Glycine max) semeados depois do cultivo e sob resíduos de palha (simulando rotação de culturas) de aveia (Avena sativa), azevém (Lolium multiflorum) e trigo (Triticum aestivum) foram estudados em experimentos conduzidos em vasos, sob condições controladas. As taxas de germinação variaram de 78 a 95\% (milho) e 68 a 97\% (soja), enquanto o índice de velocidade de emergência variou de 0.9 a 1.3 (milho) e 0,7 a 0,12 (soja). Menores taxas de germinação e índices de velocidade de emergência ocorreram em rotação de culturas com de trigo (milho) e azevém (soja). Além disso, maiores tempos médios de emergência de plântulas ocorreram em rotação de culturas com trigo (milho) e azevém (soja). Por outro lado, a rotação de cultura com aveia não afetou o índice de velocidade de emergência tampouco o tempo médio de emergência de plântulas, apesar de causar leve redução da germinação de sementes (milho e soja) e do comprimento da parte aérea (milho). Exceto para rotação de cultura com azevém (soja), a massa seca de milho e soja foi reduzida quando culturas de inverno foram cultivadas previamente. Estes resultados sugerem que um atraso e uma redução da germinação de sementes e da emergência de plântulas podem ocorrer em culturas de verão subsequentes, dependendo da espécie de inverno cultivada previamente, impactando sobre o crescimento inicial das culturas de verão.

PALAVRAS-CHAVE: alelopatia, culturas de cobertura, Glycine max, Zea mays.

No-tillage crop systems are based on the use of straw residues from a previous crop to cover the soil. The residues can show impacts on the vegetation growth after the previous crop. And the impacts can derive from physical, chemical and/or biological effects. In Southern Brazil, and many other parts of the world, 
summer crops are sowed after the cropping of the winter crops in no-tillage systems. Thus, we suppose that this management could affect the seed germination and the early plant growth of summer crops due in part to the chemical effect caused by compounds released by living winter crops and from the decay of their straw residues.

This chemical effect is agronomically called allelopathy, and it can be defined by the capacity of an organism to affect others by releasing metabolic compounds in the environment. Allelopathy includes the positive or negative effects of chemical compounds produced by plants, microorganisms, viruses and fungi that influence the growth and development of agricultural and biological ecosystems (RICE 1984, KRUSE et al. 2000). Allelopathy is taking place at companies and in farms, as natural pesticides are in focus, mainly due to increasing cases of herbicide-resistant weeds. In addition, there is a plea to reduce the application of pollutant synthetic herbicides and the need for cheaper and environmentally-safe weed management technologies (OM et al. 2002).

In plants, allelopathic compounds basically have four precursors: acetyl coenzyme A, shikimic acid, mevalonic acid and deoxyxylulose phosphate (ALBUQUERQUE et al. 2011). These compounds can be found in all parts of a plant (GATTI et al. 2004). They can be released by exudation and deposition on the leaf surface leached by rain, volatile compounds exudation from the living green parts of the plant, root exudation and finally the decay of plant residues (CHON et al. 2006).

The compounds produced by the decay of plant residues undergo several physical, chemical, and biological processes in the soil. These changes over time can either increase or decrease the phytotoxicity from decaying plant litter (AN et al. 2001). It is common that the initial decay process produces greater phytotoxicity effects and a possible negative effect also depends on the species (COCHRANE 1948). It is also very common that the decay of any plant species produces allelochemicals. In a research studying Mediterranean species, $88 \%$ of them produced some potential allelochemical (BONANOMI et al. 2005).

The decay of plant residues is predominantly presented when farmers adopt systems based on crop rotation if previous crop leaves straw on the soil. This is the case of Southern Brazilian agriculture, where winter crops, such as oat, ryegrass and wheat, are commonly sowed prior to corn or soybean in no-tillage systems. The presence of an allelopathic straw residue can control weeds by reducing seed germination and seedling development; however, allelochemicals can also affect crops of interest. It is known that the emergence of seedling and the establishment of crops following sorghum cultivation are erratic and often delayed (ROSS et al. 2001), and emergence and establishment of wheat are suppressed if growing after sunflower (PURVIS \& JONES 1990).

Although some crops, such as oat, ryegrass and wheat, are known for their allelopathic potential (KROGH et al. 2006, CAMPIGLIA et al. 2010, FAROOQ et al. 2011), to best of our knowledge, the influence of their straw on corn and soybean sowing in Southern Brazil has never been studied. The objective of this research was to test if the presence of straw residues from previously cultivated winter crops could affect the early development of subsequent summer crops.

The following winter crops were used in this study: oat cv. BRS Centauro, ryegrass cv. BRS Ponteio and wheat CV. BRS 208. The winter species were cropped prior to the following summer crops: corn cv. AgroDow 2B433HR and soybean cv. Benso F 6.0. Thus, we simulated winter-summer crop rotations.

All crops were grown in 7-L plastic pots filled with a mixture of a medium-textured soil and an organic substrate $(3: 1, \mathrm{v} / \mathrm{v})$. The pots were maintained in a growth chamber under $22 / 8{ }^{\circ} \mathrm{C}$ (day/night), $12-\mathrm{h}$ photoperiod and $80 \%$ relative humidity, for winter crops; and under $30 / 15^{\circ} \mathrm{C}$ (day/night), 14 -h photoperiod and $60 \%$ relative humidity, for summer crops. The photoperiod was kept by a mixture of incandescent and fluorescent lights delivering $850 \mu \mathrm{mol}$ m-2 s-1 photosynthetic photon-flux density.

The substrate was firstly fertilized with NPK (20-20-10 commercial formulation) at $400 \mathrm{~kg}$ ha- 1 in the winter crops. Moreover, additional fertilization was made with NPK (4-14-8 commercial formulation) at $500 \mathrm{~kg}$ ha- 1 in the summer crops.

Irrigation was made with $200 \mathrm{~mL}$ of distilled water per pot twice a day. No plant protection treatments were performed during the experiments.

Winter crops were sowed with the equivalent to 350,550 and 450 plants $\mathrm{m}-2$ of oat, ryegrass and wheat, respectively, according to technical recommendation. At the harvesting stage, seeds were removed and the winter crops were firstly cut close to the ground and additionally cut in small pieces; after that the fresh mass was placed over the soil. The winter crops plant material was maintained under the same growing conditions of the summer crops during 30 days. After this period, an equivalent to $4 \mathrm{t}$ ha- 1 of the straw residues of each winter crop was maintained over the soil. And then, the corn and soybean seeds were manually sowed from the straw residues, at $1-\mathrm{cm}$ depth in the soil, in a density of 20 seeds per pot for each 
summer crop. No straw residues were kept over the soil where the seeds were placed to avoid any physical effect. In addition, a control treatment was maintained with neither the previous cultivation of winter crops nor the presence of straw residues. The summer crops grew for 14 days after sowing (DAS).

The experiments consisted of four treatments (three winter crops plus one control treatment, for each summer crop). The experimental design was completely randomized with eight replicates, and the experiments were repeated twice.

The number of emerged seedlings (unit) was counted daily during the 14 DAS. And then, the following indices were determined based on ALBUQUERQUE et al. (2016):

Seedling emergence speed index $=(\mathrm{E} 1 / \mathrm{D} 1+\mathrm{E} 2 / \mathrm{D} 2+\ldots \mathrm{En} / \mathrm{Dn})$

where: $E n$ is the number of emerged seedlings at the dth day and $D$ is the number of days after sowing.

Seedling emergence average time (days) $=$ Lei.di $/$ Lei

where: ei is number of emerged seedlings at the ith day and di is the number of days from sowing until the measurement day(i).

The shoot length $(\mathrm{cm})$ and the dry mass accumulation $(\mathrm{g})$ were determined at 14 DAS. The length of the seedling above the ground was measured using a graduated ruler (precision $0.1 \mathrm{~cm}$ ). After that, shoot was cut and placed in an air convection oven during seven days. The dried material was weighted using a semi-analytical balance (precision $0.01 \mathrm{~g}$ ).

There was no interaction between treatments and experimental repetitions detected by a previous ANOVA test $(p>0.05)$, so all data were pooled across experimental repetitions for further analysis and presentation. Data were then analyzed by Kolmogorov-Smirnov normality test and Levene homogeneity of variances test, and no significance $(p>0.05)$ was observed by either test. It indicated the normal distribution of residues and the homogeneity of variances. Thus, data was further analyzed by ANOVA and Tukey test (both using $\mathrm{p}=0.05$ ).

Most corn and soybean seeds germinated between the fifth and eighth day. The germination rates on the 14 th day ranged from 78 to $95 \%$ for corn, and from 68 to $97 \%$ for soybean. The lowest germination rates were recorded in the crop rotation with wheat and ryegrass for corn and soybean, respectively (Figure 1).

The speed emergence index ranged from 0.9 to 1.3 for corn, and from 0.7 to 0.12 for soybean in the 14th day. The lowest speed emergence indexes were recorded in the crop rotation for wheat and ryegrass and for corn and soybean, respectively. The oat straw did not show differences in the speed index for both crops in relation to the non-cover control (Figures 2A and 2B).

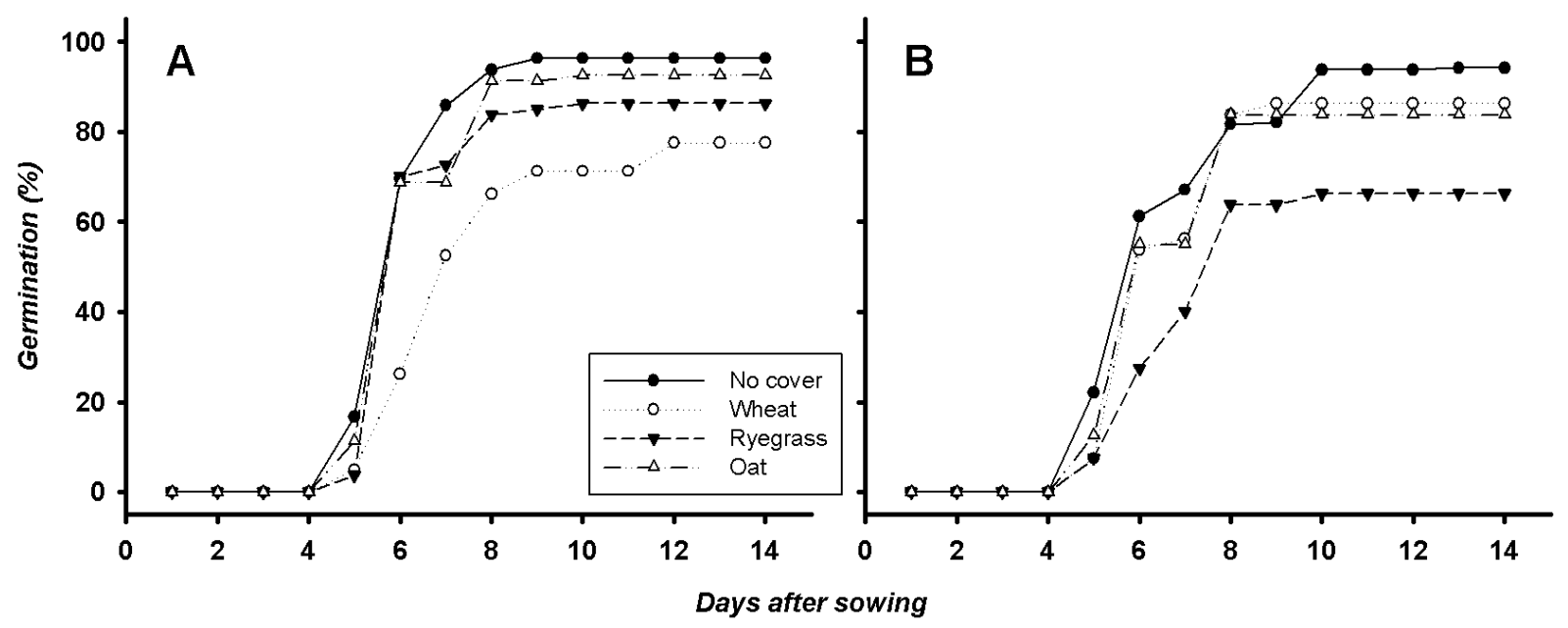

Figure 1. Corn (A) and soybean (B) seed germination during 14 days after sowing into substrate previously cultivated and covered (wheat, ryegrass and oat) or not previously cultivated and covered (no cover) by winter crops fresh residues.

The highest seedling emergence average time was observed in the crop rotation with wheat and ryegrass for corn and soybean, respectively, i.e., the germination of these crops was slower for these crop rotations compared to the non-cover controls. Meanwhile, the crop rotation with oat and ryegrass and the oat and wheat ones did not affect the average emergence time of corn and soybean, respectively, compared to their respective non-cover control (Figure 2C and 2D). 
There were no differences in the shoot length of corn seedlings in the crop rotation with wheat and ryegrass compared to the non-cover control; however, the lowest shoot length was observed in the crop rotation with oat. Meanwhile, the shoot length of soybean seedlings was similar for any crop rotation compared to the non-cover control; however, the crop rotation with wheat provided the smallest soybean shoot length compared to the other winter crops (Figure 2E and 2F).

The total dry biomass of corn and soybean seedlings in the crop rotation with winter crops was reduced in comparison to their non-cover controls, except for soybean in the crop rotation with ryegrass (Figure $2 \mathrm{G}$ and $2 \mathrm{H}$ ).

Several plants express the allelopathic phenomenon through exudation of allelochemicals (JABRAN et al. 2015). The germination rate and the emergence speed index for corn were reduced in crop rotation with wheat, and consequently the seedling emergence average time was longer, showing that crop rotation with this winter crop affected the corn development. Wheat straw reduced the germination by releasing numerous chemicals, such as hydroxamic and phenolic acid and short-chain fatty acids (ASLAM et al. 2017), during the decay produced by microorganisms, which utilize the straw as carbon and nutrient source (JABRAN 2017). Although the allelochemical effects of wheat straw reducing germination have been observed in several broadleaf weeds, such as Commelina diffusa (WANG et al. 2004) and Trianthema portulacastrum (KHALIQ et al. 2011), most of these cases describe this reduction in narrow-leaved weeds (ASLAM et al. 2017), monocotyledonous plants such as corn. In addition, there was a slight reduction in germination, plant height and biomass of corn seedlings by wheat straw in China; however, no yield reductions were observed (LI et al. 2005).

Unlike corn, seed germination and the seedling emergence speed index of soybean were reduced in crop rotation with ryegrass, prolonging its seedling emergence average time. The ryegrass species allelopathic potential, such as Lolium multiflorum, L. perenne, L. rigidum and L. temulentum on the early growth of several crops has been reported (LEMERLE et al. 1995, SAN EMETERIO 2004, AMINI et al. 2009, LEHOCHZKY et al. 2011). The ryegrass allelopathic potential is presumably due to toxic exudation from its root (MOORE et al. 2010), but also the straw decay could be contributing for this potential (LEMERLE et al. 1995). Penalties in grain yield due to ryegrass were reported in several legume crops (LEMERLE et al. 1995, MCDONALD 2003, HASHEM et al. 2011). These penalties can vary considerably among crop species and within cultivars (LEMERLE et al. 1995). Therefore, the allelopathic effects of the crop rotation with ryegrass can be more or less severe in other soybean cultivars than those observed in the Benso F 6.0 cultivar. In addition, these effects can be magnified due to the drought (SAN EMETERIO 2004). On the other hand, germination can be more sensitive to the ryegrass allelopathy than seedling growth (AMINI et al. 2009), as observed in this experiment, for both corn and soybean that showed a shoot length similar to that of the controls. This is because allelochemicals in low concentrations can stimulate the growth of plants (TEFERA 2002, AMINI et al. 2009).

Analyzing plant development, the crop rotation with all winter crops affected dry mass accumulation of corn seedling even with no negative effect on the seedling growth when using wheat and ryegrass. For soybean, the crop rotation with winter crops did not affect crop growth but wheat and oat interfered with the crop development. Oat has also affected tomato yield in another study (CAMPIGLIA et al. 2012). For ryegrass and wheat, data can be explained because literature cites negative effects on crop roots instead of shoot, which was not analyzed here (OUESLATI 2003, MOORE et al. 2010). Hence, this explanation could be extended for wheat effects on both corn and soybean crops. Analyzing soil interactions with allelochemicals is also another necessary perspective. In soil, the plant exudation can change microorganism composition and their interaction with crops (ZUO et al. 2014). These impacts do not create a non-rule use. Instead of direct burndown-sowing, a free straw in the field period could create sowing conditions, as founded in wheat (ALTIERI et al. 2011).

Further studies analyzing other cultivars and soil interactions should be done. In addition, weed suppression needs to be evaluated in future works. Seedling crop emergence and/or growth suppression could, as observed here, create conditions for non-affected weeds to interfere more on the crop production. Allelopathy could be part of an integrated weed management with potential to control herbicide resistant weeds (NORSWORTHY et al. 2011)

In conclusion, the results suggest that, depending on the winter species previously cropped, a delay and a reduction of seed germination and seedling emergence can occur in subsequent summer crops. Furthermore, the early growth of summer crops can be reduced, probably impacting crop productivity, as a consequence. 

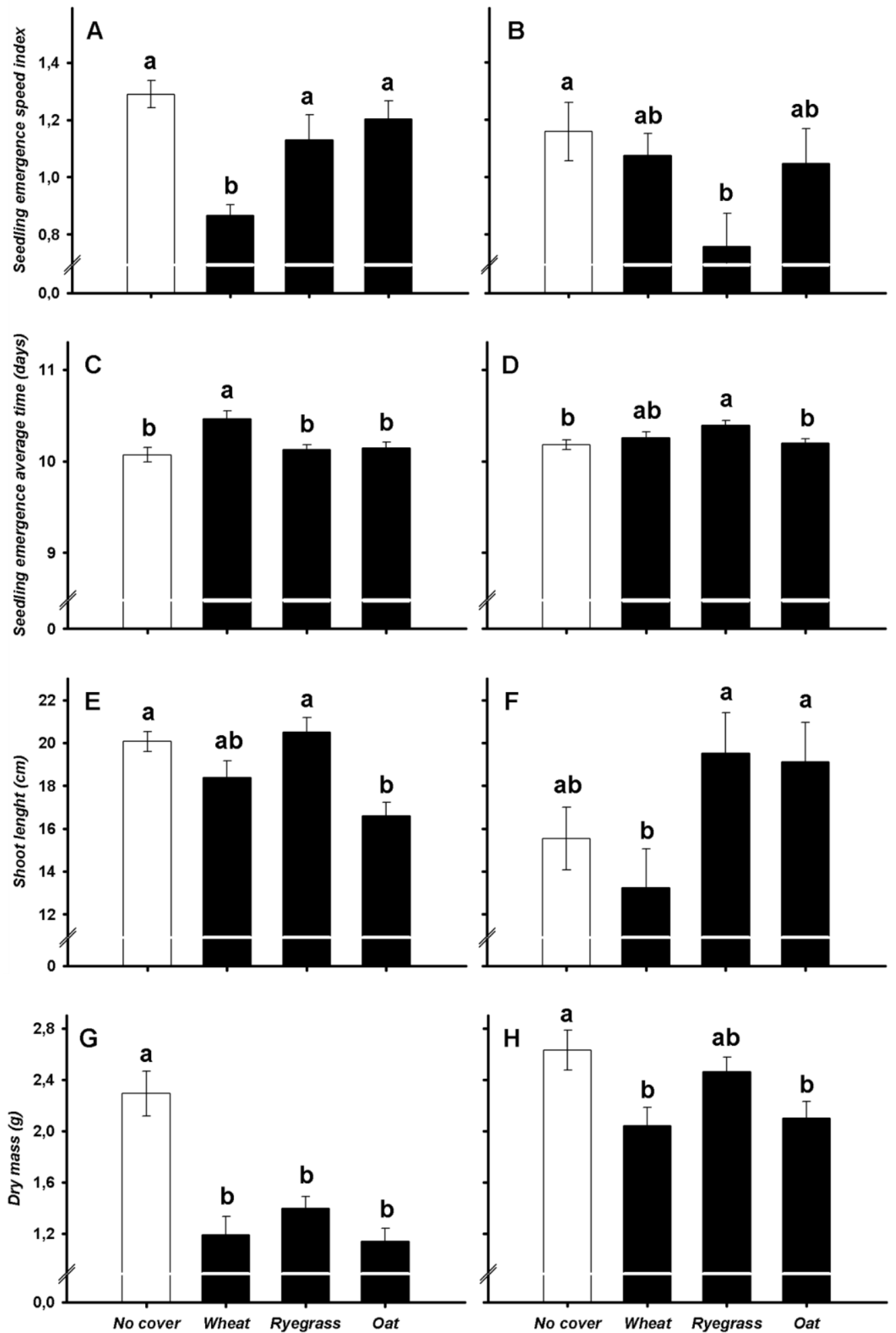

Figure 2. Corn (A) and soybean (B)seedling emergence speed index of , corn (C) and soybean (D) seedling emergence average time, corn $(E)$ and soybean $(F)$ shoot length and corn $(G)$ and soybean $(H)$ dry mass on the 14th day after sowing into substrate previously cultivated and covered (wheat, ryegrass and oat) or not previously cultivated and covered (no cover) by fresh residues of winter crops. Vertical bars denote the standard error of the mean $(n=8)$ and different lower-case letters indicate differences according to the Tukey test $(p<0.05)$.

\section{REFERENCES}

ALBUQUERQUE MB et al. 2011. Allelopathy, an alternative tool to improve cropping systems. A review. Agronomy for Sustainable Development 31: 379-395.

ALBUQUERQUE MMS et al. 2016. In vitro establishment of Comanthera curralensis, "sempre viva" native of Chapada Diamantina - Bahia. Ciência Rural 46: 991-995. 
ALTIERI MA et al. 2011. Enhancing crop productivity via weed suppression in organic no-till cropping systems in Santa Catarina, Brazil. Journal of Sustainable Agriculture 35: 1-15.

AMINI R et al. 2009. Allelopathic assessment of annual ryegrass (Lolium rigidum): Bioassays. Allelopathy Journal 24: $67-$ 76.

AN M et al. 2001. Phytotoxicity of Vulpia Residues. IV. Dynamics of allelochemicals during decomposition of Vulpia residues and their corresponding phytotoxicity. Journal of Chemical Ecology 27: 395-407.

ASLAM F et al. 2017. Allelopathy in agro-ecosystems; a critical review of wheat allelopathy-concepts and implications. Chemoecology 27: 1-24.

BONANOMI G et al. 2005. Phytotocixity dynamics of dacying plant materials. New Phytologist 169: 571-578.

CAMPIGLIA E et al. 2010. Effect of cover crops and mulches on weed control and nitrogen fertilization in tomato (Lycopersicon esculentum Mill.). Crop Protection 29: 354-363.

CAMPIGLIA E et al. 2012. Weed control strategies and yield response in a pepper crop (Capsicum annuum L.) mulched with hairy vetch (Vicia villosa Roth.) and oat (Avena sativa L.) residues. Crop Protection 33: 65-73.

CHON SU et al. 2006. Alfalfa (Medicago sativa L.) autotoxicity: Current status. Allelopathy Journal 18: 57-80.

COCHRANE VW. 1948. The role of plant residues in the etiology of root rot. Phytopathology 38: 185-196.

FAROOQ M et al. 2011. The role of allelopathy in agricultural pest management. Pest Management Science 67: $492-$ 506.

GATTI AB et al. 2004. Allelopathic activity of aqueous extracts of Aristolochia esperanzae O. Kuntze in the germination and growth of Lactuca sativa L. and Raphanus sativus L. Acta Botanica Brasilica 18: 459-472.

HASHEM A et al. 2011. Efficacy of interrow weed control techniques in wide row narrow-leaf lupin. Weed Technology 25 : 135-140.

JABRAN K et al. 2015. Allelopathy for weed control in agricultural systems. Crop Protection 72: 57-65.

JABRAN K. 2017. Wheat allelopathy for weed control. In: JABRAN K (Ed.). Manipulation of allelopathic crops for weed control. Cham, Switzerland: Springer. p.13-20.

KHALIQ A et al. 2011. Influence of wheat straw and rhizosphere on seed germination, early seedling growth and biochemical attributes of Trianthema portulacastrum. Planta Daninha 29: 523-533.

KROGH SS et al. 2006. Fate of Benzoxazinone allelochemicals in soil after incorporation of wheat and rye sprouts. Journal of Agricultural and Food Chemistry 54: 1064-1074.

KRUSE M et al. 2000. Ecological effects of allelopathic plants - a review. Silkeborg: Neri Technical Report, nํ 315. 66p.

LEHOCHZKY E et al. 2011. Allelopathic effect of Bromus spp. and Lolium spp. shoot extracts on some crops. Communications in Agricultural and Applied Biological Sciences 76: 537-544.

LEMERLE $\mathrm{D}$ et al. 1995. Losses in grain yield of winter crops from Lolium rigidum competition depend on crop species, cultivar and season. Weed Research 35: 503-509.

$\mathrm{LI} \mathrm{XJ}$ et al. 2005. Allelophatic effects of winter wheat residues on germination and growth of cabgrass (Digitaria ciliaris) and corn yield. Allelopathy Journal 15: 41-48.

MCDONALD GK. 2003. Competitiveness against grass weeds in field pea genotypes. Weed Research 43: 48-58.

MOORE JR et al. 2010. The effect of annual ryegrass (Lolium rigidum) interference on the growth of four common Australian crop species. In: Seventeenth Australian Weeds Conference. Hastings: New Zealand Plant Protection Society. p.52-55.

NORSWORTHY JK et al. 2011. Evaluation of cereal and Brassicaceae cover crops in conservation-tillage, enhanced, glyphosate-resistant cotton. Weed Technology 25: 6-13.

$\mathrm{OM} \mathrm{H}$ et al. 2002. Allelopathic response of Phalaris minor to crop and weed plants in rice-wheat system. Crop Protection 21: 699-705.

OUESLATI O. 2003. Allelopathy in two durum wheat (Triticum durum L.) varieties. Agriculture, Ecosystems \& Environment 96: 161-163.

PURVIS CE \& JONES GPD. 1990. Differential response of wheat to retain crop stubbles. II. Other factors influencing allelopathic potential: intraspecific variation. Soil type and stubble quality. Australian Journal of Agricultural Research 41: 243-252.

RICE EL. 1984. Allelopathy. 2.ed. Orlando: Academic Press. 422p.

ROSS SM et al. 2001. Weed suppression by seven clover species. Agronomy Journal 93: 820-827.

SAN EMETERIO L. 2004. Allelopathic potential of Lolium rigidum Gaud. On the early growth of three associated pasture species. Grass and Forage Science 59: 107-112.

TEFERA T. 2002. Allelopathic effects of Parthenium hysterophorus extracts on seed germination and seedling growth of Eragrostis tef. Journal of Agronomy and Crop Science 188: 306-310.

WANG G et al. 2004. Effect of returning straw to field on weeds of rice field and wheat field and the efficiency of chemical weeding. Acta Agriculturae Shanghai 1: 87-90.

ZUO S et al. 2014. Soil microbes are linked to the allelopathic potential of different wheat genotypes. Plant and Soil 378 : 49-58. 